\title{
Postharvest fish losses and unequal gender relations: drivers of the social- ecological trap in the Barotse Floodplain fishery, Zambia
}

\author{
$\underline{\text { Steven M. Cole }}^{1}, \underline{\text { Cynthia McDougall }}^{2}, \underline{\text { Alexander M. Kaminski }}^{1}, \underline{\text { Alexander S. Kefi }}^{3}$, Alex Chilala $^{4}$ and Gethings Chisule $^{5}$
}

\begin{abstract}
The Barotse Floodplain fishery is an important source of livelihood for economically poor women and men in western Zambia. Current efforts by the Department of Fisheries and the traditional authority to manage the fishery can be characterized as weak. The use of unsustainable fishing practices and overfishing are pervasive. Drawing on resilience thinking, we examine the extent to which the existing fishery-dependent livelihood context represents a social-ecological trap, i.e., a process in which rigid and persistent behavioral responses are applied because of a lack of capacity to adapt, leading to overdependence on the fishery, and ultimately, unsustainable outcomes. We use a gender lens and look beyond the primary sector (fishing) to include considerations of a secondary sector (postharvest fish processing) as an important dimension in the social-ecological trap paradigm. We present findings from an empirical research project that tested improved fish processing technologies and a communication for social change innovation as an alternate way to view a possible escape pathway from the trap not commonly recognized in the literature. The results suggest that there is value in adapting the social-ecological trap thinking to include postharvest fish losses and unequal gender relations as drivers of the trap in the floodplain fishery, and that approaches that combine technical innovation to reduce losses with social innovation to improve gender relations may hold promise for enabling fishery-dependent people to shift pathways out of social-ecological traps.
\end{abstract}

Key Words: Barotse Floodplain; gender; postharvest fish losses; small-scale fisheries; social-ecological trap; Zambia

\section{INTRODUCTION}

There is a growing interest in applying the concept of socialecological traps in complex, low-income settings such as smallscale fisheries. The concept refers to the dynamic interaction between poverty and natural resource use that creates situations that are considered undesirable in mainstream normative views of development (Cinner 2011, Boonstra et al. 2016). Specifically, in social-ecological traps, actors are understood to be applying rigid and persistent behavioral responses within their social and ecological locales, triggered in part by a lack of capacity to adapt (Carpenter and Brock 2008), and resulting in unsustainable outcomes (Cinner 2011, Enfors 2013, Boonstra and de Boer 2014, Boonstra et al. 2016). A mismatch occurs between a fast-changing environment and a slow-moving response from the social system (Laborde et al. 2016), leading to a resilient but undesirable state given the various feedbacks between the social and the ecological (Cinner 2011). Traps are path-dependent processes, not conditions, and thus, caused by a combination of events over time (Boonstra and de Boer 2014). A key value of the social-ecological trap lens has been identified as its ability to highlight "interconnections between people and their natural environment, regarding them as elements of social-ecological systems" (Hänke et al. 2017).

The trap lens has been usefully applied both in and outside of small-scale fisheries in eastern Africa (Cinner et al. 2009a,b, 2011, Enfors and Gordon 2008, Enfors 2013), Cameroon (Laborde et al. 2016), Madagascar (Hänke et al. 2017), in the lobster fishery in the eastern United States (Steneck et al. 2011), and in other settings (see Boonstra et al. 2016). The trap narrative in smallscale fishery contexts often focuses on how fishers' experiences with poverty diminish their capacities to adapt or identify (or perceive that there are) additional or alternative means or sources of livelihood, which intensifies their dependence on the fishery and leads to overexploitation given weak or missing regulatory institutions, and eventual alterations (possibly collapse) of the fishery (Cinner 2011, Cinner et al. 2011, Kittinger et al. 2013). Boonstra et al. (2016) caution against using lack of adaptability as an all-inclusive explanation for why people apply such rigid and persistent responses because it fails to appreciate the underlying causes of social-ecological traps and prevents the design of alternate interventions that could help people escape a trap.

Although current literature suggests that social-ecological traps are common in African small-scale fisheries given changing social, economic, political, and/or climatic conditions (Cinner 2011, Laborde et al. 2016, see also Onyango and Jentoft 2010), the social-ecological trap lens has not yet been applied to the fisheries of Zambia. There are 12 major fisheries in Zambia, five of which belong to the Congo River Basin and seven to the Zambezi River Basin. A mix of industrial operators and artisanal fishers commercially exploit some of these fisheries, e.g., Lakes Kariba and Tanganyika, while others are mostly fished by artisanal fishers (Musumali et al. 2009), including the Barotse Floodplain fishery (Upper Zambezi) in Western Province. The Barotse Floodplain is the second largest wetland in Zambia. Major social, political, economic, and ecological changes have occurred in and around the floodplain over the past decades (see Turpie et al. 1999, Rajaratnam et al. 2015). In line with this, Tweddle et al.'s (2015) analysis suggests that trap-like dynamics are at play throughout the Zambezi River system. These dynamics include, for example, poverty, the use of unsustainable fishing practices, weak regulatory institutions, and a growing demand for fish by urban consumers (WorldFish Center 2007, CRP AAS 2013, Madzudzo et al. 2013, Cole et al. 2015, Rajaratnam et al. 2015, Tweddle et al. 2015). Over time, these social processes have contributed to a decline in fish stocks and sizes and changes in catch composition (Mandima and Mwima 2005, WorldFish Center 2007, Musumali et al. 2009, Cole et al. 2015, Rajaratnam et al. 2015, 2016). Fewer

${ }^{1}$ WorldFish, Lusaka, Zambia, ${ }^{2}$ WorldFish, Penang, Malaysia, ${ }^{3}$ Ministry of Fisheries and Livestock, Chilanga, Zambia, ${ }^{4}$ Ministry of Agriculture, Mongu, Zambia, ${ }^{5}$ Ministry of Fisheries and Livestock, Mongu, Zambia 
fish of bigger sizes means fishers have begun targeting juveniles of larger species and the intensity of the fishing in this fishery is at an all-time high (Mandima and Mwima 2005, CRP AAS 2013, Department of Fisheries 2015, Tweddle et al. 2015). This body of evidence indicates that there is potential utility of applying a trap lens to the Barotse Floodplain fishery to unpack the complex social and ecological feedbacks and identify ways forward.

In this paper, we respond to this signal by applying the socialecological trap lens to the Barotse Floodplain fishery, with two aims. First, we aim to investigate the various mechanisms that have led to a social-ecological trap in the Barotse Floodplain fishery, including exploring postharvest fish losses and unequal gender relations as important causal factors. We do so because of the established high rates of postharvest losses in this fishery (Kefi et al. 2017), the gendered nature of losses in the processing node (Kaminski, Cole, Kefi, et al. unpublished manuscript), and the implications of losses putting increased pressure on the fishery when value chain actors return back to the fishery to retrieve or make up losses in revenues (Diei-Ouadi et al. 2015). As such, the paper offers insights into the value and complexities of integrating postharvest losses and gender issues within the trap narrative. Second, we aim to showcase potential ways women and men can transition out of the social-ecological trap in this fishery. Specifically, we draw on learning from an empirical research project that tested improved fish processing technologies and a related communication for social change innovation (community drama) to help reduce postharvest losses and improve gender relations in the fishery value chain.

\section{ANALYTICAL FRAMEWORK AND METHODS}

\section{Analytical framework}

We draw on a heuristic social-ecological trap in fisheries model developed by Cinner (2011) that highlights the factors that shape social-ecological traps in fisheries, including weak or missing regulatory institutions and poverty. Such forces drive people to use unsustainable fishing practices. Through ecological feedbacks, the result is a system moving beyond key thresholds and toward a less desirable state that may be highly resilient and difficult to return from. Inherent in the model is Ostrom's (2009) social-ecological systems framework that helps scholars and practitioners explore complex ecological, social, political, and economic systems and their interactions and relationships.

We expand the trap model for use in this paper by including explicit consideration of postharvest losses as an important factor driving the social-ecological trap in the Barotse Floodplain fishery. There are two main types of postharvest losses, physical and quality losses. Physical losses are those whereby fish gets discarded (wasted) because of a total degradation of the product, e.g., spoilage or breakage, while quality losses result in fish being sold at a reduced price because of a slight degradation of the product leading to lower value (Cheke and Ward 1998, Akande and Diei-Ouadi 2010). Part of the rationale for including losses as a potential driver of the social-ecological trap in this fishery is that research carried out in the riparian countries of the Volta Basin posits that postharvest losses lead to lower incomes and a waste of natural resources, perpetuate the use of unsustainable fishing practices, and lead to higher prices of available goodquality fish for consumers (see diagram in Diei-Ouadi et al.
2015:63). The latter encourages poorer consumers to demand for cheaper fish that, together with lower incomes due to postharvest losses, drives fishers to use unsustainable fishing practices to meet market demands. These forces coupled with the physical losses that occur have a negative impact on fisheries resources. As the intensity of the fishing increases, resources continue to decline, thus trapping fishery-dependent people in a vicious cycle. A number of determinants drive postharvest losses in the Volta Basin, including weak policies and regulation, lack of knowledge and poor handling practices, inefficient technologies, weak infrastructure and services, poor market information, and a range of gender constraints. Because women make up the bulk of the value chain actors involved in postharvest activities in Africa (de Graaf and Gabrieldi 2014), the gender implications of postharvest losses as a driver of the social-ecological trap in smallscale fisheries appear significant.

We use a gender lens when carrying out our analysis to surface the gendered power relations that shape opportunities, constraints, outcomes, and in this case, pathways in and out of the social-ecological trap in this fishery. Social and gender analyses, feminist political ecology, among other social science methods and frameworks help to explore and uncover unequal gender relations (see Locke et al. 2014, Cole et al. 2015, Ravera et al. 2016, Kawarazuka et al. 2017) that explain, for instance, why men fish or use certain fishing practices, or why women perform home-based (unpaid) tasks or are often excluded from making fisheries management decisions. Such inquiries or what Kittinger et al. (2013:353) call "diagnostic approaches" also inform the development and implementation of more holistic technical and social interventions that could lead to more resilient social and ecological systems. Kawarazuka et al. (2017:210) argue that "...gender analysis of fisheries has yet to move beyond the social domain to really engage directly with questions of ecology, which can better inform resource management [and other strategies and interventions]." It is therefore important to understand, for example, how unequal gender relations are challenged by or contribute to changing existing social-ecological systems, and how gender inequalities are shaped by people's capacities to adapt in the face of ecological shocks and stressors. The composite analytical framework used in this paper begins to fill this gap.

\section{Methods}

Data from primary and secondary sources were used for analysis for this paper. Grey and peer-reviewed secondary data and results were synthesized along with primary data results to help describe the social-ecological trap in the Barotse Floodplain fishery. Primary data analyzed were collected during the implementation of a research project on postharvest fish losses (IDRC 2014). The project was carried out by the Department of Fisheries (DoF), University of Zambia, a private company (cold store and ice supplier), and WorldFish on six fishing camps located in the Barotse Floodplain. Over 250 people formed groups in the six fishing camps in three districts of Western Province (Mongu, Senanga, and Nalolo). The groups tested improved technologies of their choice to determine if they help reduce losses when processing fish and add value to their fish products. The technologies chosen were a solar tent dryer, salting, a Chorkor kiln (improved smoking device), and ice. 
Participatory action research (PAR) was used to test the technologies over the course of two fishing seasons in 2015 and 2016. PAR is a methodology employed in many applied fields to support engagement of stakeholders in the research process to enable them to collaborate and better understand complex development challenges and find viable solutions (Reason and Bradbury 2008). Stakeholders become coresearchers and seek to answer research questions about real life concerns (see Apgar and Douthwaite 2013, Ojha et al. 2013, Apgar et al. 2017).

Data relating to postharvest losses were collected with women and men value chain actors who were testing the technologies. Qualitative data on gendered experiences dealing with postharvest losses and other fisheries-related issues were collected through in-depth interviews, focus group discussions, and participant observation. Quantitative data were collected using survey instruments. An assessment was conducted in August and September of 2016 with 52 processors ( 32 women and 20 men) to evaluate the efficacy of the fish processing technologies tested over the course of the project, including their loss-reducing capabilities and sensory (organoleptic) evaluations carried out by traders. Traders were asked to rank each consignment of fish that was processed by the assessment participants. Scores were summed (highest score was 25) and averaged.

A communication for social change tool was designed and piloted in the second fishing season, as group members continued to test the improved processing technologies that were introduced during the first fishing season. The tool comprised a manual and three drama skits that highlighted the gendered power relations that constrain some value chain actors such as women's abilities to freely participate in male-dominated activities and make decisions about finances or how they spend their time on various paid and unpaid tasks compared to men. The drama skits were piloted in three out of the six fishing camps during July, August, and September of 2016. The drama skits were performed at community level. A public discussion session occurred after each drama skit. Project participants joined their action research groups thereafter to continue discussing the key messages.

Quantitative data to evaluate the social change innovation were collected using a women's empowerment in fisheries index (WEFI) survey developed by the project. The survey consisted of modules that inquired about (among other things) participation in value chain activities and inputs into decision making about the activities and income generated, ownership of key value chain assets, and gender attitudes. Gender attitudes were assessed using a scale that was modified to fit the fishery value chain setting. Women and men were asked to respond to eight statements that reflected current gender norms and practices. Responses to each statement were summed to arrive at a total score (out of 24). Higher scores indicate more gender equal attitudes.

The WEFI survey was administered at baseline (June 2015) and again at end line (December 2016) to women and men in the three fishing camps who participated in the drama skits, as well as to people in the other three camps who were testing the technologies but did not participate in any drama skits. Given the long period of time that occurred between administering the baseline and end line surveys (around 18 months) and the time that elapsed after the last drama skit was performed and before the start of the end line survey (over two months), it is believed that the evaluation design adequately ensured that the responses provided at end line were genuine. Longitudinal data on 80 people were analyzed for this paper (45 women and men in the fishing camps who participated in the drama skits and 35 women and men in the fishing camps who did not participate in the drama skits).

Primary qualitative data were analyzed using content analysis. The primary quantitative data were analyzed using STATA (version 13). Ethical clearance to implement the research project was granted by the University of Zambia's Research Ethics Committee. The Barotse Royal Establishment (traditional authority governing Western Province) permitted the project to carry out the research. Informed consent was obtained before conducting interviews. Names used in this paper are pseudonyms.

\section{DRIVERS OF THE SOCIAL-ECOLOGICAL TRAP IN THE BAROTSE FLOODPLAIN FISHERY}

\section{Poverty and gendered power relations}

The Barotse Floodplain forms the central landscape of Western Province (Fig. 1). It spans from the Zambezi River's confluence with the Lungwebungu and Kabompo rivers (in the north) to just above the Ngonye Falls, some 230 kilometers south. The floodplain is a dynamic system, with annual floods dictating people's livelihood options as well as their movements from lowlands to uplands and vice versa when floodwaters recede. This transhumance is known locally as kuomboka and kufuluhela, respectively. Flood levels in the plain rise shortly after the rainy season begins (January-February), peak in April once the rains stop, and thereafter, recede until the following rains. It is during this latter period when the fishery is especially exploited as various fish species are channeled into the Zambezi River and people can access fishing grounds that were previously flooded. Floodplain residents employ a mixed-livelihoods strategy, engaging in fishing and postharvest activities, crop and livestock production, harvesting of aquatic and forestry products, among other activities to help secure their food and economic needs (see Rajaratnam et al. 2015). The lowlands are prime areas for fishing, cultivating crops, and grazing cattle and other livestock during the dry season when floodwaters are lowest, while the uplands are used for grazing livestock when the plains flood during the rainy season and for cultivating cassava given their nutrient-poor soils.

Western Province is the poorest region in Zambia (CSO 2016), somewhat of a paradox given the vast array of ecosystem services the floodplain supplies (CRP AAS 2012). Reasons why this paradox takes place remain underresearched. Madzudzo et al. (2013) argue that weak implementation of national policies combined with local governance arrangements strongly impact livelihoods in the floodplain. Tensions between the central government and the Barotse Royal Establishment over leadership roles are well documented (e.g., Madzudzo et al. 2013, see Caplan 1968 for a rich historical account), and likely stunt development and growth in the province.

The Litunga (king) heads the Barotse Royal Establishment, with silalo indunas (operating at the district level) and village-level indunas assisting with a variety of tasks such as distributing land, granting access to natural resources, and resolving disputes (Madzudzo et al. 2013). The Barotse Royal Establishment is a male-dominated institution and has a strong influence on shaping opportunities and well-being outcomes for women and men in 
Fig. 1. Map of Zambia, including main rivers/water bodies.

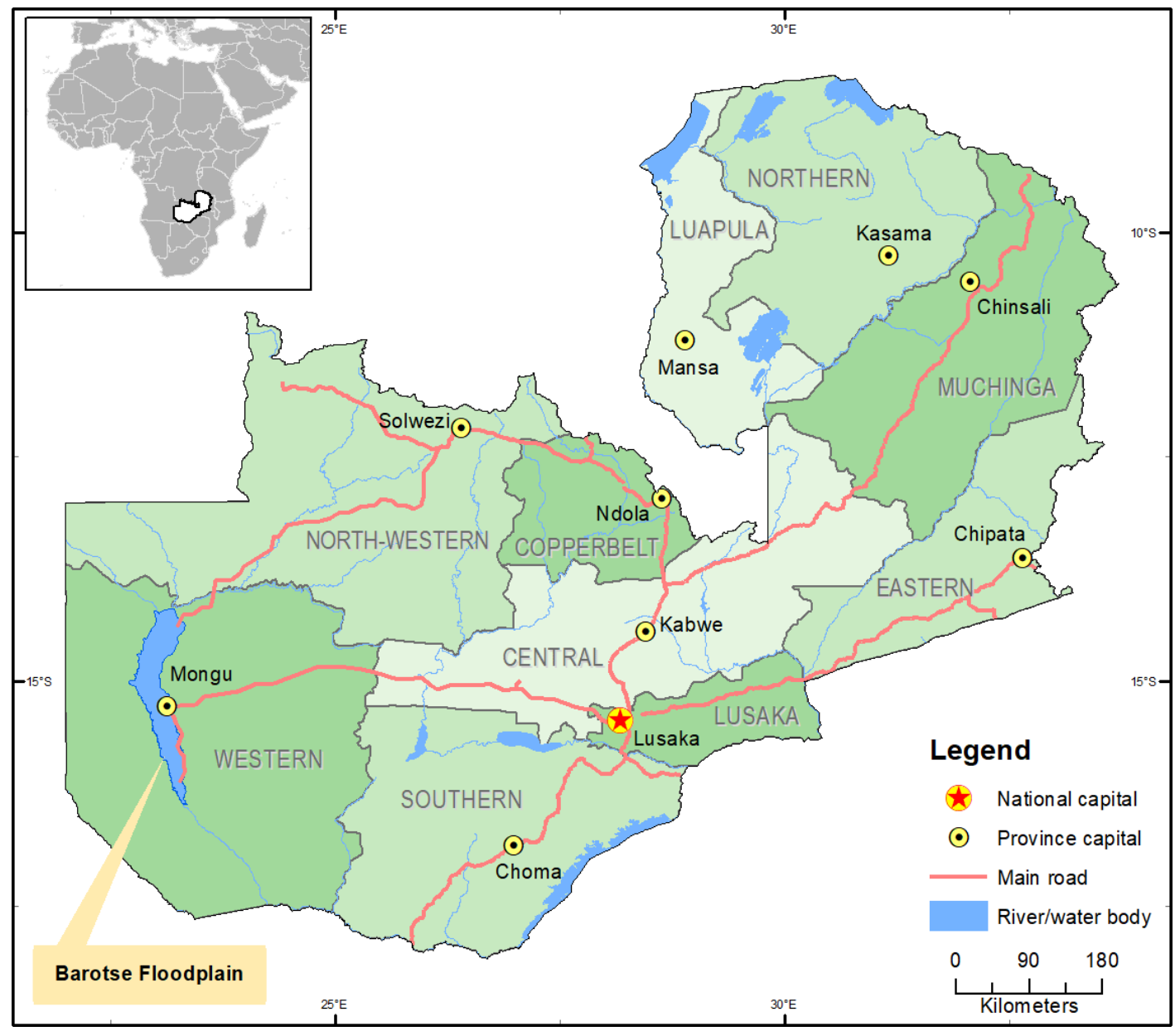

the floodplain area (Rajaratnam et al. 2015). Lozi and Mbunda are the main ethnic groups residing in Western Province, with over 20 other smaller ethnic groups composing the remaining population (CSO 2012). In 2015, the population of Western Province was estimated at 991,500 , of which $87.5 \%$ resided in rural areas (CSO 2016).

Men are the primary fishers in the floodplain, while women tend to engage in postharvest activities including the processing and trading of fish (Turpie et al. 1999, Cole et al. 2015, Rajaratnam et al. 2015, 2016). Women also fish, but their catch sizes are often smaller and the fish they catch using baskets or small nets in shallow waters is usually consumed within their homes (Cole et al. 2015). This is due in part because of the strong gender norms and power relations that govern the roles people perform in the floodplain region (Cole et al. 2015). Women are the main caretakers of their families, thus limiting their involvement in commercial fishing given that prime fishing areas are often located far from their homes (Cole et al. 2014). Instead, women tend to focus their efforts carrying out tasks such as processing and trading fish, cultivating crops, rearing smaller livestock, brewing beer, mat making, and a number of unpaid domestic duties at or around their homesteads (Rajaratnam et al. 2015). Women's participation in both paid and unpaid work (known as the "double burden") results in what Gammage (2010) calls "time poverty." As such, women's abilities to move freely outside their homes are somewhat restricted. Women's decision-making powers on the use of finances and natural resources and their ownership of agricultural and nonagricultural assets are also constrained compared to men's in the floodplain, as well as their overall well-being (Cole et al. 2015, Rajaratnam et al. 2015).

Weak regulatory institutions and unsustainable fishing practices The floodplain fishery is managed under a dual system. The DoF is mandated under the Fisheries Act No. 22 of 2011 to manage the fisheries in Zambia including Upper Zambezi (GRZ 2011). The Barotse Royal Establishment governs the fishery as a "common-property" resource, although local leaders (e.g., village indunas) charge fees (mubingu) to fish in their water bodies (Rajaratnam et al. 2016). A fishing ban is declared each year from December to end of February to help maintain the sustainability of the fishery. Madzudzo et al. (2013) argue that while this dual system is in place, the floodplain fishery operates as a "freeaccess" system (see also Simwinji 1997).

The Upper Zambezi has experienced tremendous pressure over the past decades, with increased use of different fishing gear and 
methods. Their use has resulted in a decline in fish sizes and catches and changes in catch composition (Mandima and Mwima 2005, WorldFish Center 2007, Musumali et al. 2009, CRP AAS 2013, Cole et al. 2015, Rajaratnam et al. 2015, 2016). Given the fishery is an open-access system fishers are essentially unrestricted from exploiting the fishery to maximize gains. Mandima and Mwima (2005:5) highlighted over a decade ago that there was "exceptionally intensive fishing" taking place in the Barotse Floodplain, which has escalated in recent years because of changing economic, social, political, and environmental conditions (CRP AAS 2013, Tweddle et al. 2015). Catch per unit effort (CPUE) is an indicator of the status of fish stocks, with a declining or low CPUE indicating the fishery is being overexploited (Hoggarth et al. 2006). Average CPUE (kg/fisher/ day) across the fisheries in Zambia was 14.2 in 2014 (DoF 2015). In the Upper Zambezi area, CPUE was below the national average at 11.8 .

The grey and peer-reviewed literature highlighted factors inhibiting the management of the Barotse Floodplain and other fisheries in Zambia, including weak government and traditional institutions and their lack of cooperation with local people to manage the natural resource base. One consequence of these relatively weak regulatory institutions and lack of comanagement is that overfishing using a variety of gear and methods has become increasingly popular, leading to rapid declines in the fishery's resource base, as noted above. Legislation has taken time to evolve in Zambia and embrace a more collaborative style of managing fisheries. Past acts designated the DoF as the primary custodian of the fisheries and neglected a provision for community involvement (Agricultural Consultative Forum 2009). The DoF began to involve local people in the management of fisheries' resources in the early 1990s (WorldFish Center 2007) and amended the Fisheries Act of 1974 in 2007 so that each fishery had designated management areas, whereby a committee would develop and implement a management plan (Musumali et al. 2009). The act also provisioned for the establishment of a fund at national level to facilitate community-based approaches to management and develop the sector. The Fisheries Act of 1974 was replaced in 2011 (GRZ 2011). Given a lack of human and financial resources, and arguably the lack of mechanisms to effectively engage local women and men, many of the said strategies and extension services that were designed to involve local people in the management of Zambian fisheries have not been adequately implemented or provided by the DoF (see also Musumali et al. 2009). For example, in 2015 the DoF operated at $18.3 \%$ staffing capacity and was allocated $20.4 \%$ of their annual budget by the central Government (DoF 2016). No data were recorded on issuance of fishing licenses, surveillance patrols, and community sensitization meetings by the DoF in Western Province in 2015, which means these activities did not take place.

Tweddle et al. (2015) and others (CRP AAS 2013, Rajaratnam et al. 2015, 2016) have documented some of the gear used more recently in the floodplain fishery, including large monofilament nets (known locally as sefa-sefa) that enable the harvesting of not only large and small species but also juveniles, fish fry, and eggs. Male fishers primarily fish for economic gains, use sefa-sefa, and fish during the closed season (Cole et al. 2015, Rajaratnam et al. 2015, 2016). Mosquito nets are also used, especially by women (Rajaratnam et al. 2015). Madzudzo et al. (2013) argue that the local stewards of the fishery, indunas, on the whole are unable to adequately enforce regulations against the use of nets with small mesh sizes or other practices deemed "illegal" according to normative views given a lack of incentives and capacities. Rajaratnam et al. (2016) report that some indunas are empowered to govern who does and does not fish in their local water bodies by charging higher mubing $u$ to fishers who use gear that extract large amounts of fish.

\section{Increased demand for (smaller) fish}

Catches in some of the fisheries in Zambia known for their small pelagic populations have declined over the years. Catches of kapenta, a small pelagic (Limnothrissa miodon) in Lake Kariba, declined by $48.5 \%$ from 2013 to 2014, while the effort (boat days) increased, resulting in a CPUE of 0.07 tons/boat/night (DoF 2015). This was the lowest CPUE observed over the past 10 years (2004 to 2014), indicating overexploitation (and subsequent lower supply) of kapenta from this lake (Musumali et al. 2009, Chali et al. 2014). Kapenta has until more recently been a major source of nutrient-dense fish for poor urban consumers (Longley et al. 2014). It now appears the Barotse Floodplain fishery is being targeted as a source of small fish, which in some cases are actually juveniles of larger species such as Synodontis spp., Oreochromis andersonii, and Hydrocynus vittatus (CRP AAS 2013, Tweddle et al. 2015). Based on participant observation (and photo evidence, see Fig. 2) both in fishing camps and in markets in urban centers, employing such fishing practices is partially fueled by local and distant traders who are supplying the demand for relatively cheap, small dried fish in poor urban markets in Zambia.

Fig. 2. Photographs of juveniles of larger fish species caught and dried in the Barotse Floodplain fishery.

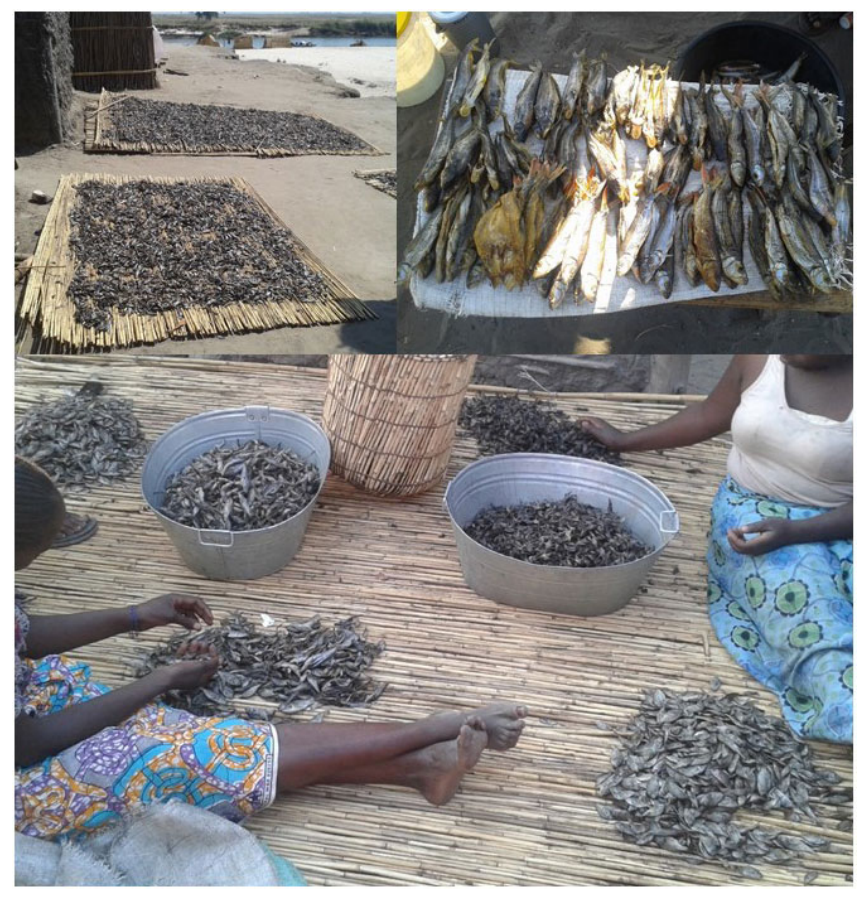

Estimates indicate that close to 80,000 metric tons (MT) of additional fish are required to overcome the current supply deficit in the country (DoF 2016). Fish imports as well as aquaculture 
production increased over the past couple years in Zambia (by $39.9 \%$ and $18.0 \%$, respectively) to help fill this gap. Along with population growth, another possible reason for the alleged increase in harvesting juveniles of larger fish species from the Barotse Floodplain fishery is due to the recent increase in farmed tilapia production in the country. Farmed fish is cost-prohibitive for most poor urban consumers (Genschick et al. 2018). Juveniles of larger fish species thus provide a cheaper source of fish to meet the growing demand for small fish by these consumers (see DieiOuadi et al. 2015 for a similar argument for the case in the Volta Basin).

\section{Postharvest losses}

The gap between fish supply and demand is increasing in many sub-Sharan African countries in part because of postharvest losses (Ababouch 2009, Finegold 2009). According to a FAO publication on postharvest losses (2016a:2, see also Diei-Ouadi et al. 2015 and FAO 2016b), "[t]he most obvious means to increase fish supply, even without increased landings, is to reduce losses of what is presently caught ... Post-harvest losses pose not only a threat to food and nutrition security but also to the livelihoods of the value chain actors involved and to natural resources sustainability." Thus, if postharvest losses were reduced, less fish would be required to be harvested from the Barotse Floodplain and other fisheries in Zambia to meet local and national demands for fish.

According to catch assessment surveys carried out in 2014 by the DoF (2015), 80,826 MT of fish were caught overall in Zambia and 7714 MT in Upper Zambezi, which includes the Barotse Floodplain fishery. The catch in Upper Zambezi was a $32.0 \%$ increase from 2013. Recorded dry and fresh fish trading in Zambia and in Western Province was 3884 MT and 166 MT, respectively. It is estimated that around $65 \%$ of fish from capture fisheries in Zambia is processed using open-air sun drying or smoking methods because of long distances between where the fish is caught and sold and lack of cold chains (Agricultural Consultative Forum 2009, DoF 2015). Average total fish loss (both physical and quality losses) is around 30\% in sub-Saharan Africa (FAO 2016a), with the majority being quality losses (DieiOuadi et al. 2015). Research carried out in the Barotse Floodplain fishery found that total losses among a sample of value chain actors averaged $29.3 \%$, with physical losses at $6.4 \%$ and quality losses at $22.9 \%$ (Kaminski, Cole, Kefi, et al. unpublished manuscript). The processing node experienced the highest percentage of losses compared to the fishing and trading nodes, and women processors experienced three times more physical losses than men processors. This indicates that although processors are more at risk of experiencing fish losses, women processors are more at risk than men processors.

Based on these numbers, we estimate that 5173 MT of fish was totally wasted in Zambia in 2014 and 494 MT in Upper Zambezi, amounting to ZMK87,938,688 (US\$9,405,207) and ZMK12,095,552 (US\$1,293,642) worth of discarded fish (physical loss), respectively ${ }^{[1]}$. Assuming aquaculture production and imports remain constant in the country, if physical losses reduced by $3 \%$ (from $6.4 \%$ to $3.4 \%$ ), this would theoretically mean 2748/262 MT of fish from the capture fisheries would not be required.

In the Barotse Floodplain fishery, losses occur throughout the value chain. Although women are the primary processors and traders of dried fish, male fishers also process their catches when they are unable to sell fresh. The most common methods used to process fish are open-air sun drying on reed/papyrus mats (either raised or placed on the ground) and smoking using large drums or over open fire.

Physical and quality losses are caused by a number of technical reasons, but also because of certain gender constraints that especially limit women's abilities to process fish with minimal losses. Fish that remains too long in gill nets while waiting to be harvested can begin to spoil. Predation by animals and theft by humans lead to losses for people sun drying their fish unattended in the open. Women who process while also carrying out household duties, can overprocess their fish. This results in immediate or future breakages for women when storing or transporting fish. One key informant strongly believed women experience more losses because they are starting out with fish of lower quality, or what Diei-Ouadi et al. (2015:49-50) call the "loss transfer" phenomenon from male fishers to women processors, which manifests in different ways according to local dynamics. In the Barotse Floodplain one reason the transfer of loss occurs is because some women are restricted from traveling long distances given their caregiving and domestic responsibilities and not as capable as men carrying heavy loads of fish. These restrictions prevent them from accessing fresher, better-quality fish found in more distant places in the floodplain. According to some research participants, men incur losses simply because they lack experience in processing compared to women and often hastily process their fish. Canoes that capsize when transporting fish from camps to urban centers cause major losses for people trying to sell their fish in distant markets that attract higher prices. Taking long periods of time to sell fish in such markets that lack adequate storage facilities or during peak times of the season when competition is high, leads to physical and quality losses for traders, respectively. Paying for accommodation, food, and drink when selling fish in these markets gradually diminishes any real returns people make selling their fish.

During qualitative interviews, fishers, processors, and traders indicated their consignments of fish experienced a wide range of losses (from no losses at all, to $10 \%$, to $75 \%$ ) depending on their node of primary operation and individual circumstances. Similar to the situation in the fisheries in the Volta Basin (Diei-Ouadi et al. 2015), it is forwarded here that some value chain actors attempt to make up for these losses by either fishing more intensely or using certain gear and methods to harvest more fish, more easily, and more quickly, or purchasing additional fish to process and resell locally or elsewhere. These "trips back to the fishery" are partially fueled by the large gap in the supply of fish in Zambia, and especially the supply of cheaper (often smaller) fish to urban poor consumers. Consequently, value chain actors have persistently exploited this fishery to the point that juveniles of larger species can be frequently found sun drying on mats in camps throughout the floodplain and sold in markets in and outside the province.

\section{RESULTS FROM THE PILOT PROJECT}

Improved postharvest fish processing technologies

Table 1 presents results of the evaluation of the improved processing technologies that were tested using PAR over the course of two fishing seasons. The assessment used the following 
Table 1. An evaluation of improved postharvest fish processing technologies in the Barotse Floodplain fishery.

\begin{tabular}{lccc}
\hline \hline & & \multicolumn{2}{c}{ Improved technologies } \\
\cline { 2 - 3 } Assessment criteria & Salting & Solar tent & Chorkor kiln \\
\hline Reduce losses & high & high & low \\
Reduce time burden & high & low & low \\
Improve quality of fish products & high & high & low \\
Impact on livelihoods & high & high & medium \\
Local market available & no & yes & yes \\
& & & high \\
\end{tabular}

criteria to evaluate the technologies: their abilities to reduce losses and time burdens and improve the quality of the products, their impact on livelihoods, and whether there is demand for the processed products in local markets.

Overall, the improved technologies reduced losses compared to the methods people used prior to the start of the project. The salting technology decreased the time and labor burdens of women compared to the open-air sun drying method because salting requires little or no effort once the fish is salted and stored for 24 hours. A woman processor named Mendai explained that salting enabled her to perform other tasks, both unpaid and paid, such as washing clothes and gardening while her fish is being salted. Mendai had been unable to carry out these tasks before when smoking her fish because she feared the fish would burn. Processors mentioned that salting extends the shelf life of the fish, thus they could salt the fresh fish that they were unable to sell, accumulate the products, and sell at a later date. Salted products are more durable and do not break when storing or transporting. After desalting and cooking the fish, processors said the flesh is soft and tastes similar to fresh fish. The major constraint prohibiting many from adopting the technology is lack of a local market, as salted fish is not commonly consumed in Zambia but instead in the Democratic Republic of Congo (DRC). Nonetheless, some traders transport their salted fish for sale in the Zambia/DRC border town, Kasumbalesa.

Sun drying can take up to four days to adequately dry fish, and does not safeguard the fish from predation by domesticated animals or theft by humans compared to when using the salting and solar tent drying technologies. During one interview with a woman processor named Janet, a pig approached her fish drying on a reed mat placed on the ground and stole a small portion of her fish. She indicated that when sun drying this is all one can do because the fish requires constant turning and the chasing away of animals, a common theme among respondents. Similar examples exist for processors who must devote time to chasing away birds, dogs, or chickens when sun drying their fish in the open using mats raised or placed on the ground.

The solar tent dryer proved successful in reducing losses, and produced a high-quality and attractive-looking product with a rich golden color. The use of the solar tent dryer does not require a processor to turn the fish because the dryer essentially works like an oven drying the fish from above and below. This aspect of the solar tent dryer also produces a flatter dried fish that appears easier to store/package and transport, and presumably results in fewer breakages. People can use the solar tent dryer to dry fish (and other foods such as cassava and vegetables) during the rainy season, unlike when using the open-air sun drying method. The solar tent dryer did not significantly reduce the time it takes to dry fish compared to open-air sun drying.

Icing was found to be a superior technology in all regards when compared to using the local cooling system, whereby fresh fish is wrapped in aquatic plants (sometimes sand) and constantly wetted to preserve the fish. The main issue is that ice is not accessible to most floodplain residents. Group members who could access ice did, however, test a few strategies to prolong the frozen state of ice, for example, by burying the ice blocks deep in the sand covered in saw dust or by breaking the ice block into small pieces and applying them in between layers of fish and storing them in a locally made ice box lined inside with plastic. Women and men who used ice said they were able to engage in other paid and unpaid activities while their fish was on ice, unlike with those who use the cooling system because it requires constant application of water to keep the fish cool and fresh.

In terms of influence on livelihoods, during the assessment people indicated that their use of the improved technologies helped them increase their incomes, part of which they used to pay their children's school fees and purchase food and common household items. As one means of testing this in situ, local and distant traders were organized during the assessment to provide feedback to the women and men who processed their fish using both the improved and existing technologies. Overall, their average estimated values of the consignments of fish processed using the improved technologies were higher compared to the values of fish processed using the existing technologies. For example, traders indicated they would pay on average ZMK5 (roughly US\$0.50) more for the consignment of salted fish compared to the sundried fish. Traders said they would pay ZMK21.3 (roughly US\$2.10) more for iced fish than for fish preserved using the local cooling system. Likewise, consignments of salted fish received a significantly higher sensory score on average than consignments of sundried fish (18.6 versus $16.5: \mathrm{P}=0.0063$ ), while the average sensory score received by traders for consignments of iced fish was 11.0 points higher than the consignments of fish preserved using the local cooling system $(\mathrm{P}<0.0001)$.

\section{Communication for social change innovation}

Average gender attitude scores increased by $28.6 \%(\mathrm{P}<0.0001)$ for those who participated in the drama skits compared to only $11.7 \%(\mathrm{P}=0.0286)$ for those from camps where drama skits were not performed. The average score of men who participated in the drama skits increased more than any other subgroup, by $35.7 \%$ $(\mathrm{P}<0.0001)$. And while the average gender attitude score increased by $13.3 \%$ for those men from camps where drama skits were not performed, the change was not significant at or below the $5 \%$ level. 
Fig. 3. A social-ecological trap: Interactions between external drivers and social and ecological variables in the Barotse Floodplain fishery. The outcome is a feedback process that locks the system to a development path where ecosystem services decline, outputs, e.g., fish primarily harvested by men and processed by women, remain low, and value chain actors remain relatively poor.

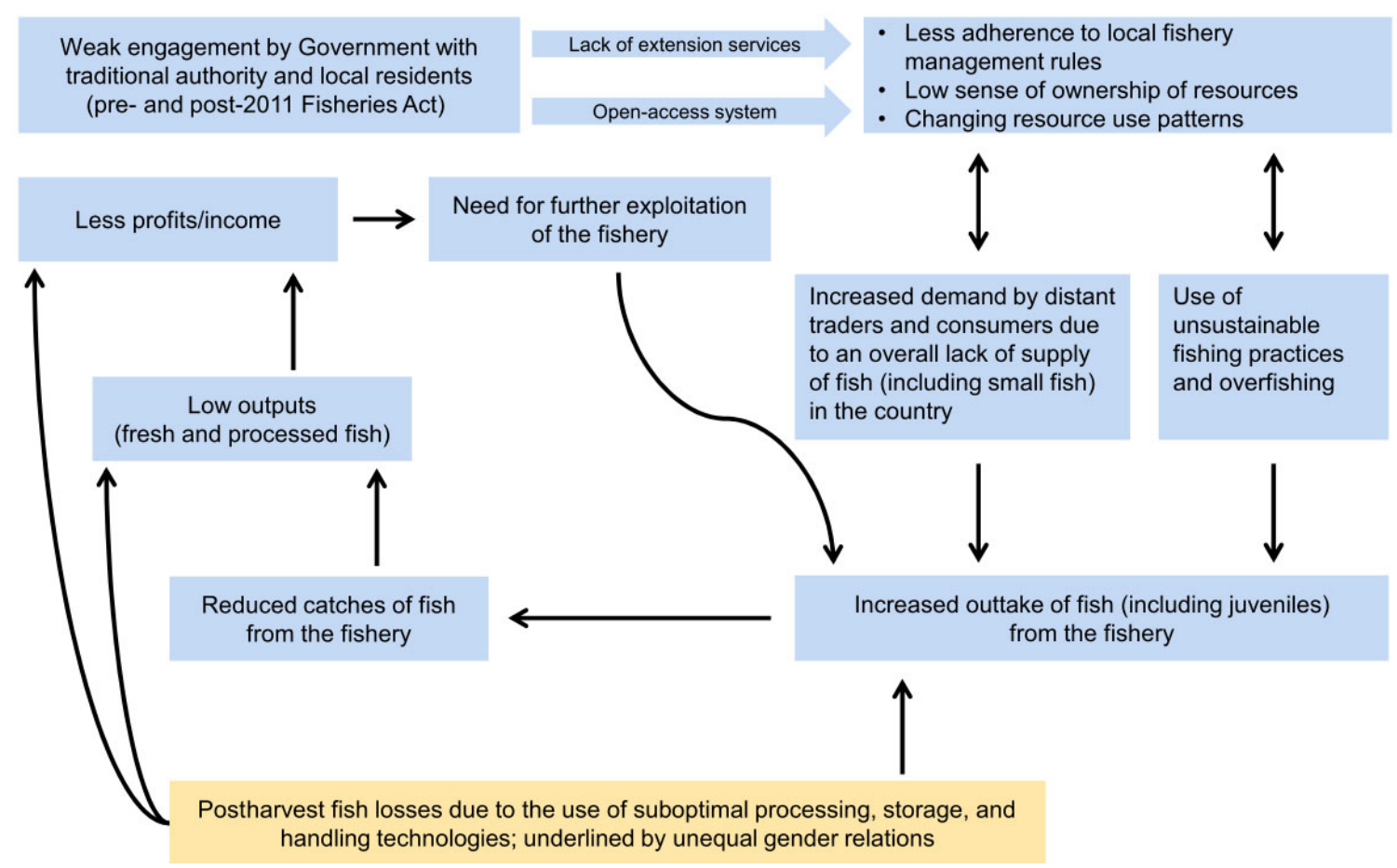

Changes in women's empowerment were noted in the three areas assessed: participation in fisheries-related value chain activities, decision making, and ownership of assets. Specifically, women who participated in the drama skits increased their involvement in fishing from baseline $(5 \%)$ to end line $(75 \%)$, and the change was significant at the $1 \%$ level. The percentage of women who participated in the drama skits who made large contributions to intra-household decisions about the income generated from processing fish increased by $49 \%(\mathrm{P}=0.0025)$. Amongst men who participated in the drama skits, a significant shift was observed in their fishing gear ownership status from sole ownership to joint ownership with their spouses. At baseline, 50\% responded that they owned the fishing gear outright, and at end line, only $19 \%$ stated they were the sole owners of the fishing gear $(\mathrm{P}=0.0419)$. Forty-four percent of men who participated in drama skits responded that they jointly owned the fishing gear with their spouses at baseline and this increased to $76 \%$ at end line $(\mathrm{P}=$ 0.0433). Similar changes in women's empowerment for those who did not participate in the drama skits were not found.

\section{DISCUSSION}

The review of the secondary literature, presented together with some of the primary data collected by the research project highlighted how the dynamics of the social and ecological systems of the Barotse Floodplain are inextricably linked. Figure 3 presents a depiction of the social-ecological trap in this fishery. Forces such as poverty, weak (or sometimes missing) regulatory institutions, changing resource use patterns, and the use of unsustainable fishing practices are front and center in the trap narrative. As the local and distant demands for fish from this fishery have increased, outtake of fish (including juveniles) has also increased, which has led to a reduction in fish catches (decline in CPUE), lower outputs, presumably less profits and incomes, and ultimately, increased need to further exploit the fishery. People's experiences dealing with postharvest losses leads to the supply of poorer quality fish, reduced output, lower incomes, and creates the need for more fish to make up for losses and meet the growing demand for fish in Zambia.

Unequal gender relations are an underlying cause of postharvest losses in this fishery (see Fig. 4), leading some value chain actors into the social-ecological trap. Women disproportionately experience postharvest losses because of time constraints and their lack of decision-making powers and access to processing but also storage and handling technologies. They also lack access to training and other knowledge-generating opportunities, which are low for most rural people in Zambia, but especially for women. Other factors such as market forces prohibit value chain actors from selling their fish during peak times of the year or because of poor or crowded market conditions or having a lack of bargaining skills, all of which are often gendered.

An implication of unequal gender relations being an underlying cause of postharvest losses, which in turn contribute to increased outtake and a reduction in the productivity of the fishery, is that technologies or technology-focused approaches alone cannot alter the feedback loops to leverage a change in the system's overall 
Fig. 4. Unequal gender relations as an underlying cause of postharvest fish losses in the Barotse Floodplain fishery.

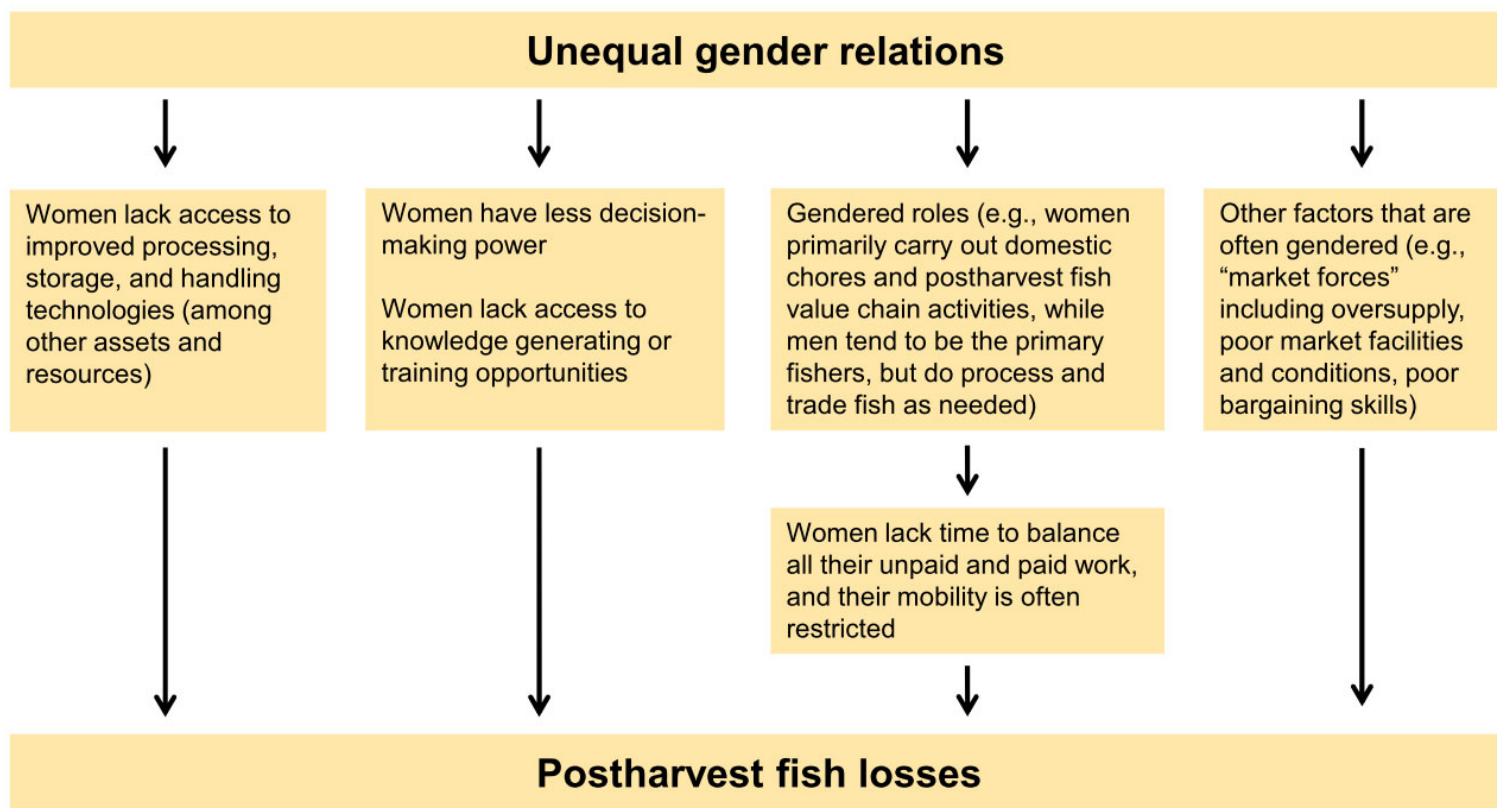

dynamics (see Laborde et al. 2016). Including postharvest losses and unequal gender relations as drivers of the social-ecological trap in this fishery, and in the fisheries of the Volta Basin (DieiOuadi et al. 2015), sheds new light on how complex social and ecological feedbacks in small-scale fisheries can be, thus requiring diverse toolkits and perspectives to uncover such complexity (see Laborde et al. 2016). Our analysis provides a foundation for future studies to build on and further nuance the intricate feedbacks that lead to social-ecological traps in this and other small-scale fisheries. In so doing, additional technologies, approaches, and social change innovations that aim to alter the system's dynamics can be designed, tested, and scaled, including more holistic fisheries management strategies to help fishery-dependent people transition out of or escape the social-ecological trap.

The research project aimed to generate learning on how to reduce postharvest losses in this fishery by piloting both improved fish processing technologies and a social change innovation with fishers, processors, and traders. The results showcase that the technologies and social change innovation helped identify a pathway out of a situation where postharvest losses reduce the quality and availability of fish as well as incomes and where unequal gender relations constrain certain actors from participating in and benefiting from the fishery value chain.

The findings from the assessment of the improved postharvest fish processing technologies demonstrated that on the whole the improved technologies reduced losses and the time it takes to process fish. In line with Diei-Ouadi et al. (2015), as postharvest losses are reduced at scale, these results mean that less fish may be harvested from this fishery to meet local and national demands, thus reducing pressure on the fishery and providing an escape route for value chain actors from the given social-ecological trap. The gender implications of these results are equally important because they suggest that the use of the improved technologies, in terms of labor saving, frees up time women devote to processing. Theoretically, this enables women to engage in other productive activities that could further enhance their livelihood security (IFAD 2016).

The results from the evaluation of the social change innovation imply that gender relations amongst local value chain actors improved over the course of the project in part because of the messaging the drama skits delivered and the subsequent discussions that occurred at community and group levels. On the whole, the social change innovation helped bring about positive changes in men value chain actors' attitudes regarding gender equality. Changes in gender attitudes have resulted in other settings where men were engaged using similar interventions (e.g., see Verma et al. 2006, Van den Berg et al. 2013). The social change innovation also helped increase women value chain actors' participation in intra-household financial decision making. Projects that integrated group discussions or gender dialogues and that achieved comparable outcomes have been reported elsewhere (see USAID 2015 for examples). Given that unequal gender relations were identified as an underlying cause of postharvest losses in this fishery, these results further indicate that such gender constraints can be lifted to help reduce losses and help women and men transition out of the social-ecological trap (see also DieiOuadi et al. 2015).

Whether floodplain residents will actually reduce the numbers or quantities of fish they harvest or purchase to process and trade because of a reduction in losses is an important research question to explore as the technologies get adopted at a larger scale. Does a reduction in losses help conserve fishery resources? What is evident from our research is that a pathway to climb out of the social-ecological trap is clearer for some women who are 
responsible for processing fish and who experience more physical losses in this context.

A risk is that as the use of the improved fish processing technologies increases and greater returns on people's investments also increase, more (not less) fish will be harvested, processed, and traded, possibly leading to the eventual collapse of the fishery. To avoid such a scenario, Cinner (2011) proposed changes that need to occur, for instance, strengthening fisheries management strategies. Postharvest losses are rarely considered when formulating fisheries management strategies worldwide (Tesfay and Teferi 2017, see Njock et al. 2009 for an exception). Although the research project did not incorporate an explicit fisheries management focus, the learning generated on how to develop and implement communication for social change innovations in a fisheries context could be drawn upon to help integrate postharvest losses into a broader, more gender-aware fisheries management strategy.

\section{CONCLUSION}

In this paper we evidenced that the current state of the Barotse Floodplain fishery represents a social-ecological trap. This is significant because it indicates that fisheries policy and management strategies and future development interventions will need to consider and address more holistically the multiple and complex feedbacks between social and ecological processes that drive people into the trap in this fishery. We expanded the socialecological trap framing by including postharvest losses as one factor increasing the demand for and supply of fish, thus improving understanding of why some people fall into the trap in this fishery. Moreover, by using a gender lens the paper was able to nuance its analysis of the social and ecological systems of the floodplain fishery, thereby enriching the description of the social-ecological trap. Specifically, using a gender lens that investigated the gendered power relations in this fishery, we surfaced findings important to identifying ways out of the trap. Women bear the brunt of postharvest losses in this and other fisheries because of their dominant role in processing and the harmful gender norms and power relations that shape losses, such as women's lack of decision-making powers and their involvement in unpaid and paid work that limits the time women can devote to processing.

Finally, we also surfaced that combining technical and social change innovations may open up a window of opportunity for value chain actors to escape the social-ecological trap. Specifically, findings from the assessments of the improved processing technologies and communication for social change innovation suggest that combining the technologies with the social change innovation reduced losses and addressed some of the unequal gender relations that cause losses, thus paving a way out of the social-ecological trap in this fishery. More broadly, fisheries management strategies in such complex settings could embrace the use of these combined technical and social change innovations to engage with local people on how to reduce the use of unsustainable fishing practices and postharvest losses, and therefore, better sustain the fishery. Future research should explicitly test over time whether such innovations lead to a decline in overdependence on the fishery as value chain actors require fewer trips back to the fishery when postharvest losses reduce.
${ }^{[1]}$ Average price of fresh and dried fish (combined) in Zambia in 2014 was ZMK 17/kg and ZMK24.5/kg in Western Province (DoF 2015).

Responses to this article can be read online at: http://www.ecologyandsociety.org/issues/responses. $\mathrm{php/9950}$

\section{Acknowledgments:}

Funding support for the research came from the International Development Research Center (IDRC) and the Australian Centre for International Agricultural Research (ACIAR) under the Cultivate Africa's Future fund (No. 107837). This research was undertaken as part of the CGIAR Research Program on Aquatic Agricultural Systems ( AAS) and Fish Agrifood Systems (FISH). The authors thank all donors who supported this program through their contributions to the CGIAR Fund. The authors wish to thank the Department of Fisheries officers who helped collect the data that were analyzed for this paper and the project participants for taking part in the research. The authors extend their sincere gratitude to the two anonymous reviewers for constructive feedback on earlier drafts of the manuscript. Any errors are the responsibilities of the authors.

\section{LITERATURE CITED}

Ababouch, L. 2009. Fish utilization and trade. Pages 377-398 in Fisheries, sustainability and development: fifty-two authors on coexistence and development of fisheries and aquaculture in developing and developed countries. Royal Swedish Academy of Agriculture and Forestry (KSLA), Stockholm, Sweden.

Agricultural Consultative Forum. 2009. The status of fish population in Zambia's water bodies. Zambia Food Security Research Project (FSRP), Lusaka, Zambia.

Akande, G., and Y. Diei-Ouadi. 2010. Post-harvest losses in smallscale fisheries: case studies in five sub-Saharan African countries. FAO Fisheries and Aquaculture Technical Paper No. 550. Food and Agriculture Organization of the United Nations, Rome, Italy.

Apgar, M., and B. Douthwaite. 2013. Participatory action research in the CGIAR research program on aquatic agricultural systems. CGIAR Research Program on Aquatic Agricultural Systems. WorldFish Center, Penang, Malaysia.

Apgar, J. M., P. J. Cohen, B. D. Ratner, S. De Silva, M.-C. Buisson, C. Longley, R. Bastakoti, and E. Mapedza. 2017. Identifying opportunities to improve governance of aquatic agricultural systems through participatory action research. Ecology and Society 22(1):9. http://dx.doi.org/10.5751/ES-08929-220109

Boonstra, W. J., E. Björkvik, L. J. Haider, and V. Masterson. 2016. Human responses to social-ecological traps. Sustainability Science 11(6):877-889. http://dx.doi.org/10.1007/s11625-016-0397$\underline{x}$

Boonstra, W. J., and F. W. de Boer. 2014. The historical dynamics of social-ecological traps. Ambio 43(3):260-274. http://dx.doi. org/10.1007/s13280-013-0419-1 
Caplan, G. L. 1968. Barotseland: the secessionist challenge to Zambia. Journal of Modern African Studies 6(3):343-360. http:// dx.doi.org/10.1017/S0022278X00017456

Carpenter, S. R., and W. A. Brock. 2008. Adaptive capacity and traps. Ecology and Society 13(2):40. http://dx.doi.org/10.5751/ ES-02716-130240

Central Statistical Office (CSO). 2012. Census of population and housing 2010: national analytical report. CSO, Lusaka, Zambia.

Central Statistical Office (CSO). 2016. 2015 Living conditions monitoring survey report. CSO, Lusaka, Zambia.

CGIAR Research Program on Aquatic Agricultural Systems (CRP AAS). 2012. Resilient livelihoods and food security in coastal aquatic agricultural systems: investing in transformational change. Project Report: AAS-2012-28. CGIAR Research Program on Aquatic Agricultural Systems, Penang, Malaysia.

CGIAR Research Program on Aquatic Agricultural Systems (CRP AAS). 2013. Improved fisheries management in the Barotse Floodplain of Zambia: an urgent call for action. Brief: AAS-2013-40. CGIAR Research Program on Aquatic Agricultural Systems, Penang, Malaysia.

Chali, M., C. G. Musuka, and B. Nyimbili. 2014. The impact of fishing pressure on Kapenta (Limnothrissa miodon) production in Lake Kariba, Zambia: a case study of Siavonga District. International Journal of Agriculture, Forestry and Fisheries 2 (6):107-116.

Cheke, R. A., and A. R. Ward. 1998. A model for evaluating interventions designed to reduce post-harvest losses. Fisheries Research 35:219-227. http://dx.doi.org/10.1016/S0165-7836(98) $\underline{00074-5}$

Cinner, J. E. 2011. Social-ecological traps in reef fisheries. Global Environmental Change 21(3):835-839. http://dx.doi.org/10.1016/ j.gloenvcha.2011.04.012

Cinner, J. E., C. Folke, T. Daw, and C. C. Hicks. 2011. Responding to change: using scenarios to understand how socioeconomic factors may influence amplifying or dampening exploitation feedbacks among Tanzanian fishers. Global Environmental Change 21(1):7-12. http://dx.doi.org/10.1016/j.gloenvcha.2010.09.001

Cinner, J. E., T. Daw, and T. R. McClanahan. 2009a. Socioeconomic factors that affect artisanal fishers' readiness to exit a declining fishery. Conservation Biology 23(1):124-130. http://dx.doi.org/10.1111/j.1523-1739.2008.01041.x

Cinner, J. E., T. R. McClanahan, T. M. Daw, N. A. J. Graham, J. Maina, S. K. Wilson, and T. P. Hughes. 2009b. Linking social and ecological systems to sustain coral reef fisheries. Current Biology 19(3):206-212. http://dx.doi.org/10.1016/j.cub.2008.11.055

Cole, S. M., R. Puskur, S. Rajaratnam, and F. Zulu. 2015. Exploring the intricate relationship between poverty, gender inequality and rural masculinity: a case study from an aquatic agricultural system in Zambia. Culture, Society and Masculinities 7(2):154-170.

Cole, S. M., B. van Koppen, R. Puskur, N. Estrada, F. DeClerck, J. J. Baidu-Forson, R. Remans, E. Mapedza, C. Longley, C.
Muyaule, and F. Zulu. 2014. Collaborative effort to operationalize the gender transformative approach in the Barotse Floodplain. Program Brief: AAS-2014-38. CGIAR Research Program on Aquatic Agricultural Systems, Penang, Malaysia.

de Graaf, G., and L. Garibaldi. 2014. The value of African fisheries. FAO Fisheries and Aquaculture Circular. No. 1093. Food and Agriculture Organization of the United Nations, Rome, Italy.

Department of Fisheries (DoF). 2015. 2014 Fisheries statistics annual report. Department of Fisheries, Chilanga, Zambia.

Department of Fisheries (DoF). 2016.2015 Departmental annual report. Department of Fisheries, Chilanga, Zambia.

Diei-Ouadi, Y., B. K. Sodoke, F. A. Oduro, Y. Ouedraogo, K. Bokobosso, and I. Rosenthal. 2015. Strengthening the performance of post-harvest systems and regional trade in smallscale fisheries: case study of post-harvest loss reduction in the Volta Basin riparian countries. FAO Fisheries and Aquaculture Circular No. 1105. Food and Agriculture Organization of the United Nations, Rome, Italy.

Enfors, E. I. 2013. Social-ecological traps and transformation in dryland agro-ecosystems: using water system innovations to change the trajectory of development. Global Environmental Change 23(1):51-60. http://dx.doi.org/10.1016/j.gloenvcha.2012.10.007

Enfors, E. I., and L. J. Gordon. 2008. Dealing with drought: the challenge of using water system technologies to break dryland poverty traps. Global Environmental Change 18:607-616. http:// dx.doi.org/10.1016/j.gloenvcha.2008.07.006

Finegold, C. 2009. The importance of fisheries and aquaculture to development. Pages 353-364 in Fisheries, sustainability and development: fifty-two authors on coexistence and development of fisheries and aquaculture in developing and developed countries. Royal Swedish Academy of Agriculture and Forestry (KSLA), Stockholm, Sweden.

Food and Agriculture Organization of the United Nations (FAO). 2016a. A strategy for sustainable fisheries and aquaculture in the Volta Basin riparian countries' post-harvest chains and regional trade. FIAM/C1121, FAO Fisheries and Aquaculture Circular. FAO, Rome, Italy.

Food and Agriculture Organization of the United Nations (FAO). 2016b. The state of world fisheries and aquaculture 2016: contributing to food security and nutrition for all. FAO Fisheries and Aquaculture Circular. FAO, Rome, Italy.

Gammage, S. 2010. Gender, time poverty and Amartya Sen's capability approach: evidence from Guatemala. Pages 71-76 in Chant S, editor. The international handbook of gender and poverty: concepts, research, policy. Edward Elgar, Cheltenham, UK.

Genschick, S., P. Marinda, G. Tembo, A. M. Kaminski, and H. S. Thilsted. 2018. Fish consumption in urban Lusaka: the need for aquaculture to improve targeting of the poor. Aquaculture, in press. http://dx.doi.org/10.1016/j.aquaculture.2018.03.052

Government of the Republic of Zambia (GRZ). 2011. The Fisheries Act, 2011. Government of the Republic of Zambia, Lusaka, Zambia. 
Hänke, H., J. Barkmann, C. Coral, E. Enfors Kaustky, and R. Marggraf. 2017. Social-ecological traps hinder rural development in southwestern Madagascar. Ecology and Society 22(1):42. http:// dx.doi.org/10.5751/ES-09130-220142

Hoggarth, D. D., S. Abeyasekera, R. I. Arthur, J. R. Beddington, R. W. Burn, A. S. Halls, G. P. Kirkwood, M. McAllister, P. Medley, C. C. Mees, G. B. Parkes, G. M. Pilling, R. C. Wakeford, and R. L. Welcomme. 2006. Stock assessment for fishery management - a framework guide to the stock assessment tools of the Fisheries Management Science Programme (FMSP). FAO Fisheries Technical Paper. No. 487. Food and Agriculture Organization of the United Nations, Rome, Italy.

International Development Research Centre (IDRC). 2014. Improving fish post-harvest management and marketing in Malawi and Zambia. IDRC, Ottawa, Ontario, Canada. [online] URL: https://www.idrc.ca/sites/default/files/sp/Documents $\% 20$ EN/Fishprocessing-and-marketing-in-Zambia-and-Malawi.pdf

International Fund for Agricultural Development (IFAD). 2016. Reducing rural women's domestic workload through laboursaving technologies and practices. Teaser. IFAD, Rome, Italy.

Kawarazuka, N., C. Locke, C. McDougall, P. Kantor, and M. Morgan. 2017. Bringing analysis of gender and social-ecological resilience together in small-scale fisheries research: challenges and opportunities. Ambio 46:201-213. http://dx.doi.org/10.1007/ $\underline{\text { s13280-016-0814-5 }}$

Kefi, A. S., S. M. Cole, A. M. Kaminski, A. Ward, and N. L. Mukandawire. 2017. Physical losses of fish along the value chain in Zambia: a case study of Barotse Floodplain. International Journal of Fisheries and Aquaculture 9(10):98-107. http://dx.doi. org/10.5897/IJFA2017.0638

Kittinger, J. N., E. M. Finkbeiner, N. C. Ban, K. Broad, M. H. Carr, J. E. Cinner, S. Gelcich, M. L. Cornwell, J. Z. Koehn, X. Basurto, R. Fujita, M. R. Caldwell, and L. B. Crowder. 2013. Emerging frontiers in social-ecological systems research for sustainability of small-scale fisheries. Current Opinion in Environmental Sustainability 5:352-357. http://dx.doi.org/10.1016/ j.cosust.2013.06.008

Laborde, S., A. Fernández, S. C. Phang, I. M. Hamilton, N. Henry, H. C. Jung, A. Mahamat, M. Ahmadou, B. K. Labara, S. Kari, M. Durand, B. Mark, P. Scholte, N. Xiao, R. Ziebe, and M. Moritz. 2016. Social-ecological feedbacks lead to unsustainable lock-in in an inland fishery. Global Environmental Change 41:13-25. http://dx.doi.org/10.1016/j.gloenvcha.2016.08.004

Locke, C., P. Kantor, M. Morgan, and N. Kawarazuka. 2014. The social-ecological systems framework: potential for analysing gender and social change? DEV research briefing 10. University of East Anglia, Norwich, UK.

Longley, C., S. H. Thilsted, M. Beveridge, S. Cole, D. B. Nyirenda, S. Heck, and A.-L. Hother. 2014. The role of fish in the first 1,000 days in Zambia. Institute of Development Studies Special Collection September:27-35. http://opendocs.ids.ac.uk/opendocs/ handle/123456789/4384

Madzudzo, E., A. Mulanda, J. Nagoli, J. Lunda, and B. D. Ratner. 2013. A governance analysis of the Barotse Floodplain system, Zambia: identifying obstacles and opportunities. Project Report:
AAS-2013-26. CGIAR Research Program on Aquatic Agricultural Systems, Penang, Malaysia.

Mandima, J., and H. Mwima. 2005. Baseline fish biodiversity surveys - experiences from the Zambezi River, Southern Africa. World Wildlife Fund, Lusaka, Zambia.

Musumali, M. M., S. Heck, S. M. C. Husken, and M. Wishart. 2009. Fisheries in Zambia: an undervalued contributor to poverty reduction. Policy Brief 1913. The WorldFish Center/The World Bank, Penang, Malaysia.

Njock, J.-C., E. H. Allison, L. Westlund, and A. Konana. 2009. Innovations in fisheries co-management, and the challenge of mobility. Pages 267-280 in Fisheries, sustainability and development: fifty-two authors on coexistence and development of fisheries and aquaculture in developing and developed countries. Royal Swedish Academy of Agriculture and Forestry (KSLA), Stockholm, Sweden.

Ojha, H. R., A. Hall, and R. Sulaiman V. 2013. Adaptive collaborative approaches in natural resource governance. Earthscan, London, UK.

Onyango, P., and S. Jentoft. 2010. Assessing poverty in small-scale fisheries in Lake Victoria, Tanzania. Fish and Fisheries 11:250-263. http://dx.doi.org/10.1111/j.1467-2979.2010.00378.x

Ostrom, E. 2009. A general framework for analyzing sustainability of social-ecological systems. Science 325:419-422. http://dx.doi.org/10.1126/science.1172133

Rajaratnam, S., S. M. Cole, K. M. Fox, B. Dierksmeier, R. Puskur, F. Zulu, S. J. Teoh, and J. Situmo. 2015. Social and gender analysis report: Barotse Floodplain, Western Province, Zambia. Program Report: AAS-2015-18. CGIAR Research Program on Aquatic Agricultural Systems, Penang, Malaysia.

Rajaratnam, S., S. M. Cole, C. Longley, F. Kruijssen, and S. Sarapura. 2016. Gender inequalities in access to and benefits derived from the natural fishery in the Barotse Floodplain, Zambia, Southern Africa. Asian Fisheries Science Special Issue 29S:49-71.

Ravera, F., I. Iniesta-Arandia, B. Martín-López, U. Pascual, and P. Bose. 2016. Gender perspectives in resilience, vulnerability and adaptation to global environmental change. Ambio 45 (Supplement 3):235-247. http://dx.doi.org/10.1007/s13280-016-0842-1

Reason, P., and H. Bradbury. 2008. Sage handbook of action research: participatory inquiry and practice. Second edition. Sage, London, UK. http://dx.doi.org/10.4135/9781848607934

Simwinji, N. 1997. Summary of existing relevant socio-economic and ecological information. Report to IUCN on Zambia's Western Province and Barotseland. The World Conservation Union (IUCN) Regional Office of Southern Africa, Harare, Zimbabwe.

Steneck, R. S., T. P. Hughes, J. E. Cinner, W. N. Adger, S. N. Arnold, F. Berkes, S. A. Boudrea, K. Brown, C. Folke, L. Gunderson, P. Olsson, M. Scheffer, E. Stephenson, B. Walker, J. Wilson, and B. Worm. 2011. Creation of a gilded trap by the high economic value of the Marine lobster fishery. Conservation Biology 25(5):904-912. http://dx.doi.org/10.1111/j.1523-1739.2011.01717. $\underline{x}$ 
Tesfay, S., and M. Teferi. 2017. Assessment of fish post-harvest losses in Tekeze dam and Lake Hashenge fishery associations: northern Ethiopia. Agriculture \& Food Security 6:4. http://dx.doi. org/10.1186/s40066-016-0081-5

Turpie, J., B. Smith, L. Emerton, and J. Barnes. 1999. Economic value of the Zambezi Basin wetlands. Zambezi Wetlands Conservation and Resource Utilization Project. The World Conservation Union (IUCN), Regional Office for Southern Africa, HJ Ruitenbeek Resource Consulting, Ltd and University of Capetown, Capetown, South Africa.

Tweddle, D., I. G. Cowx, R. A. Peel, and O. L. F. Weyl. 2015. Challenges in fisheries management in the Zambezi, one of the great rivers in Africa. Fisheries Management and Ecology 22:99-111. http://dx.doi.org/10.1111/fme.12107

United States Agency for International Development (USAID). 2015. Working with men and boys to end violence against women and girls: approaches, challenges, and lessons. USAID, Office of the Senior Coordinator for Gender Equality and Women's Empowerment and the Office of Gender Equality and Women's Empowerment, Washington, D.C., USA.

Van den Berg, W., L. Hendricks, A. Hatcher, D. Peacock, P. Godana, and S. Dworkin. 2013. 'One Man Can': shifts in fatherhood beliefs and parenting practices following a gendertransformative programme in Eastern Cape, South Africa. Gender and Development 21(1):111-125. http://dx.doi.org/10.1080/13552074.2013.769775

Verma, R. K., J. Pulerwitz, V. Mahendra, S. Khandekar, G. Barker, P. Fulpagare, and S. K. Singh. 2006. Challenging and changing gender attitudes among young men in Mumbai, India. Reproductive Health Matters 14(28):135-143. http://dx.doi. org/10.1016/S0968-8080(06)28261-2

WorldFish Center. 2007. Proceedings of the international workshop on the fisheries of the Zambezi Basin, 31 May-2 June 2004, Livingstone, Zambia. The WorldFish Center Conference Proceedings 75. The WorldFish Center, Penang, Malaysia. 